Proceedings

\title{
Sexual Size Dimorphism Does Not Change Systematically in Latitude/Longitude Gradient, but its Standard Deviation De- clines Significantly
}

\author{
Tatyana A Gordienko ${ }^{1}$, Anatoly A Saveliev ${ }^{2}$, Natalya I Eremeeva ${ }^{3}$, Nadezhda L Ukhova ${ }^{4}$, Iraida G Vorobyova 5 , \\ Igor A Solodovnikov ${ }^{6}$, Anatoliy L Anciferov ${ }^{7}$, Rifgat R Shagidullin' ${ }^{1}$, Lyudmila G Tselishcheva ${ }^{8}$, Raisa A \\ Sukhodolskaya ${ }^{1, *}$
}

Citation: Gordienko, T.A.; Saveliev, A.A.; Eremeeva, N.I.; Ukhova, N.L.; Vorobyova, I.G.;Solodovnikov, I.N.; Anciferov, A.L.; Shagidullin, R.R.; Tselishcheva, L.G.;Sukhodolskaya, R.A. Sexual Size Dimorphism Does Not Change Systematically in Latitude/Longitude Gradient, but its Standard Deviation Declines Significantly, in Proceedings of the 1st International Electronic Conference on Entomology, 1-15 July 2021, MDPI: Basel, Switzerland,

doi:10.3390/IECE-10703

Published: 28 July 2021

Publisher's Note: MDPI stays neutral with regard to jurisdictional claims in published maps and institutional affiliations.

Copyright: (c) 2021by the authors. Submitted for possible open access publication under the terms and conditions of the Creative Commons Attribution (CC BY) license (http://creativecommons.org/licenses /by/4.0/).
1 The Institute of Problems in Ecology and Mineral Wealth, Tatarstan Academy of Sciences, eiseniata@gmail.com; sukhodolskayaraisa@gmail.com, shagidullin@mail.ru

2 Kazan (Volga Region) Federal University, anatoly.saveliev.aka.saa@gmail.com

3 Kemerovo State University, neremeeva@mail.ru

4 Visimskiy Nature Reserve, ukh08@yandex.ru

5 Mariy State University, vigir@mail.ru

6 Educational establishment, Vitebsk State P.M. Masherov University, iasolodov@mail.ru

Kostroma Museum-Reserve, ancifer.ost@yandex.ru

8 State Reserve "Nurgush", tselishevalg@mail.ru

* Correspondence: sukhodolskayaraisa@gmail.com; Tel.: (89503152619; 88432759273)

+ Presented at the 1st International Electronic Conference on Entomology (IECE 2021), 1-15 July 2021; Available online: https://iece.sciforum.net/.

Abstract: The clarifying ecogeographical rules contributes greatly into evolutionary theory. We investigated 9 samples of ground beetle Pterostichus oblongopunctatus Fabricius, 1787 from regions differing in location at 4 degrees in latitude and 57 degrees in longitude. Sexual size dimorphism (SSD) was estimated in 6 morphometric traits. In total 3847 individuals were measured. SSD in different traits changed sometimes significantly in investigated gradients. But its mean values for all 6 traits together had the same values in all regions. Standard deviation in SSD values declines significantly towards the north and towards the east

Keywords: Sexual Size Dimorphism, ground beetles, geographical gradients.

\section{Introduction}

A main concept of ecology is that organisms live in a multidimensional space. In this space dimensions are interpreted as hypothetical axes of various quantifiable environmental factors. The latter impact organisms and the organisms in turn response to the factors [1]. The number of such factors is vast and their importance is well known at all ecological levels [2-3]. Identifying these factors and modeling their effects on the functional traits of species is a key issue in ecology. In insects that undergo metamorphosis, morphological traits are particularly sensitive to developmental conditions because their size is established during development through the proliferation and growth of cells in the imaginal disks [4]. Besides growth, trajectories vary across tissues and thus plasticity response to various environmental parameters can be tissue-specific [5]. Different traits are not similarly response to environmental factors). For example, D. melanogaster wings are more sensitive to temperature, femur and thorax are more sensitive to nutrition and 
genitalia are the least sensitive to environmental perturbations [5]. The existence of population genetic variation for plasticity is confirmed. Often it is sex-biased (sexual size dimorphism, SSD). However, most studies that investigate intraspecific variation in plasticity rely on a single morphological measurement [6-8], which is often used as a proxy for body size, and the prevalence of divergence of tissue-specific changes in morphological developmental plasticity between populations of the same species remains an open question. In our study we tried to avoid such the limitations taking into research intra-specific variation several traits in ground beetle Pterostichus oblongopunctatus (Fabricius, 1887). Ground beetles populations are an attractive model for investigating the evolution of morphological plasticity within species, as many species inhabit a range of habitats with high to low environmental heterogeneity along a latitudinal cline [9]. Our previous study in $P$. oblongopunctatus showed that its body size varied significantly in latitude gradient from one region to another, but the whole trend displayed stableness [10]. Females and males had the similar directions of body size variation but some discrepancies occurred. In present study we hypothesize: (i) SSD in studied beetle is female-biased; (ii) SSD varies in geographical gradients (latitude and longitude).

\section{Material and Methods}

Pterostichus oblongopunctatus (Fabricius, 1787) is a small-medium size beetle. It is recorded throughout European ecosystems and prefers litter-rich soils of humid deciduous broadleaved forests [11]. The species is noted in habitats of significant temperature span and found susceptible to multitude of environmental factors. Animal's metric traits to both human activity and natural conditions are noted [12-13]. Despite of textbook attribution to ecosystems of Europe, given species is found abundant further in Palearctic and in Mesouralic and Siberian ecosystems. Impact of different ecosystems, geographic location is noted for similar species [14] yet remain not entirely researched in huge span of environmental factors for $P$. oblongopunctatus.

Study design. In our work we widened the data set that had been used in our previous work [10]. We added material from new provinces and new sampled beetles. Then we classified all regions according to their geographical position and they received their numbers. Those numbers are mentioned further in figures in Results section and were as fol-

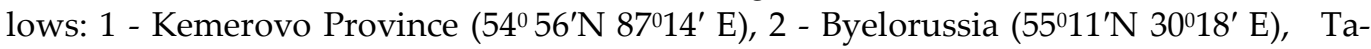
tarstan Republic, where two distant localities were studied - 3 - Saraly (55022' N 49 $13^{\prime}$ E) and 4 - Raifa (55056' N 48 42' E), 5 - Mariy El Republic (56037' N 47057' E), Sverdlovsk Province with two distant localities - 6 - Revda city suburbs and 7 - (57050' N 59055' E) and 7 - Visimskiy Reserve (57024' N 59033' E), 8 - Kostroma Province (57046' N 40056' E), 9 Kirov Province (58036' N 49039'E).

Utilized morphometric data corresponded to six linear scalar float recordings as dependent variables and is given for following values (denoting letters are given as Cyrillic transliteration of reference material's source) by R.A. Sukhodolskaya [14] (Figure 1). 


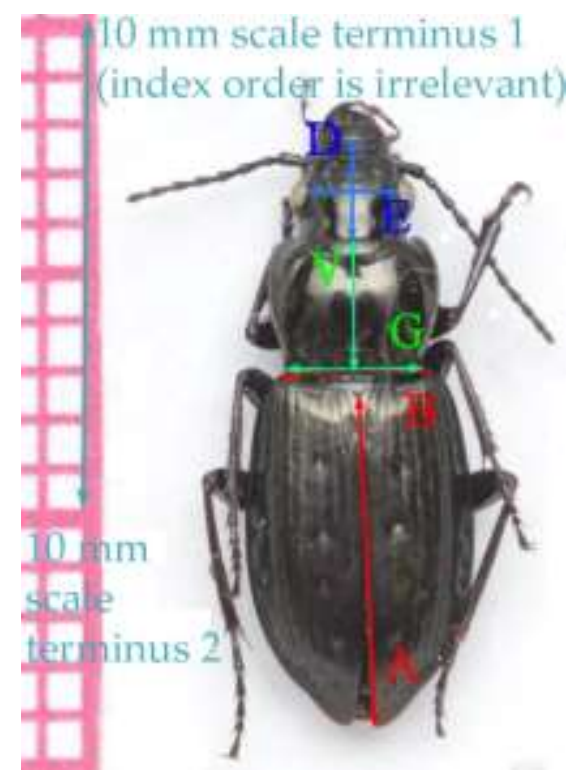

Figure 1. Placement of morphometric measurements: A - Elytra length as distance between posterior end of scutellum and terminus of right elytron (in absence case of intact right elytron, left one is acceptable), B - Elytra width as distance between anterior-distal corners of elytra, V - Pronotum length measured along of central furrow pronotum, G - Pronotum width as distance between posterior corners of pronotum, D - Head length as distance between labrum and juncture of occiput and postgena (This trait despite of its clear wording, is prone to erroneous deviations due to mobility of head joints and following inconsistency of the anterior terminus), E-Head width as distance between proximal innermost sides of eyes.

Morphometric data was collected from images taken by Nikon D5100 camera with custom opaque light disperser and a box with opaque reflective surface. Measurements were made using program, designated specifically for the given method of measurement and utilized distance between manually pointed out elements of photos' arrays as terminal point of measurements and fiducial scale, using the last to bind real scale to array output data.

Measured sample size is presented in Table 1.

Table 1. Sample size of measured P. oblongopunctatus

\begin{tabular}{cccc}
\hline & $\begin{array}{c}\text { Number } \\
\text { of studied plots }\end{array}$ & Females & Males \\
\hline Kemerovo & 1 & 231 & 96 \\
Byelorussia & 2 & 12 & 37 \\
Saraly & 3 & 328 & 354 \\
Raifa & 4 & 224 & 356 \\
Mariy El & 5 & 91 & 77 \\
Sverdlovsk & 6 & 368 & 385 \\
Visimsky & 7 & 342 & 291 \\
Kostroma & 8 & 174 & 170 \\
Kirov & 9 & 92 & 54 \\
\hline
\end{tabular}

Data processing. To study variation of sexual size dimorphism (SSD) we calculated the size dimorphism index (SDI) [15] by dividing the trait size of the females by the trait size of males and subtracting one, resulting in negative SDI when males trait is larger and positive values of SDI when females trait is larger. 


\section{Results and Discussion.}

In all cases (exuding the only one - head length in 6-th region) SDI was positive, indicating that females were larger by all traits. So SSD in P. oblongopunctatus was femalebiased like in the other ground beetles species [16]. SSD values varied by regions, being the lowest by all traits in Sverdlovsk region (Revda city suburbs) (Figure 2). SSD was expressed similarly in traits relating to separate organs of the animals, i.e. its values were equal in elytra, pronotum and head length and width, respectively. This fact meant that beetles studied developed harmoniously and their size proportions were not disturbed. The highest values of SSD in pronotum parameters were in Belarus and Mariy El, then they decreased towards the North. SSD in other traits was about the same in all regions excluding the 6-th one (Sverdlovsk-Revda).

We averaged SSD values for all traits in each region and performed mean SSD variation in latitude gradient (Figure 3): it did not change significantly (excluding the 6-th region). The same was shown for longitude gradient (Figure 4). So SSD had the single value in the populations of $P$. oblongopunctatus along $4^{0}$ in latitude and $57^{\circ}$ in longitude. But standard deviation of SSD differed by regions significantly (Figure 5,6). It was the highest in Belarus and Kostroma and the lowest - in Sverdlovsk-Revda. But in both cases it had the negative trend especially expressed in longitude gradient.

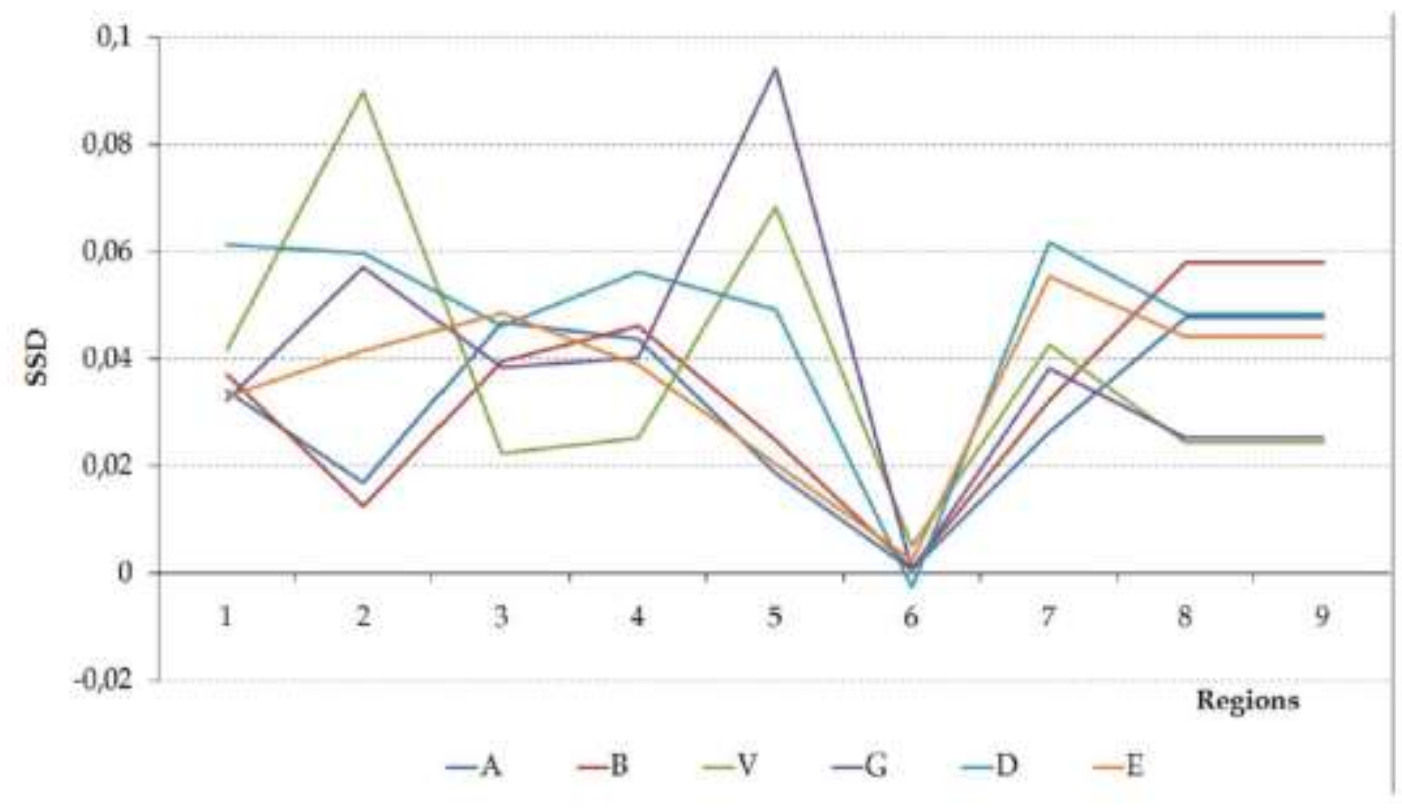

Figure 2. SSD values in different traits in P. oblongopunctatus in studied regions (A- elytra length, B- elytra width, V-pronotum length, G-pronotum width, D-head length, E- distance between eyes). 


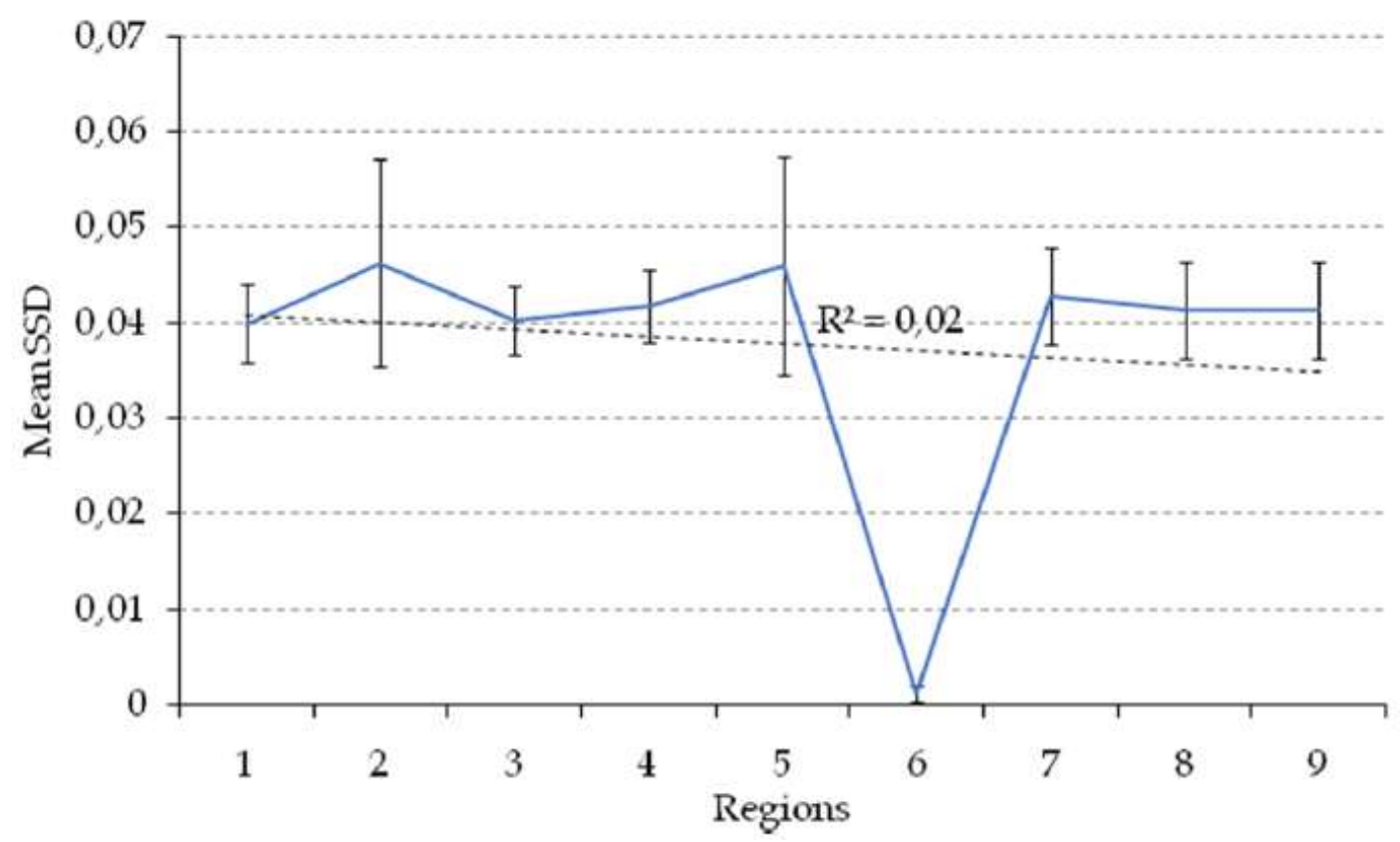

Figure 3. Mean SSD variation. The regions were arranged northwards.

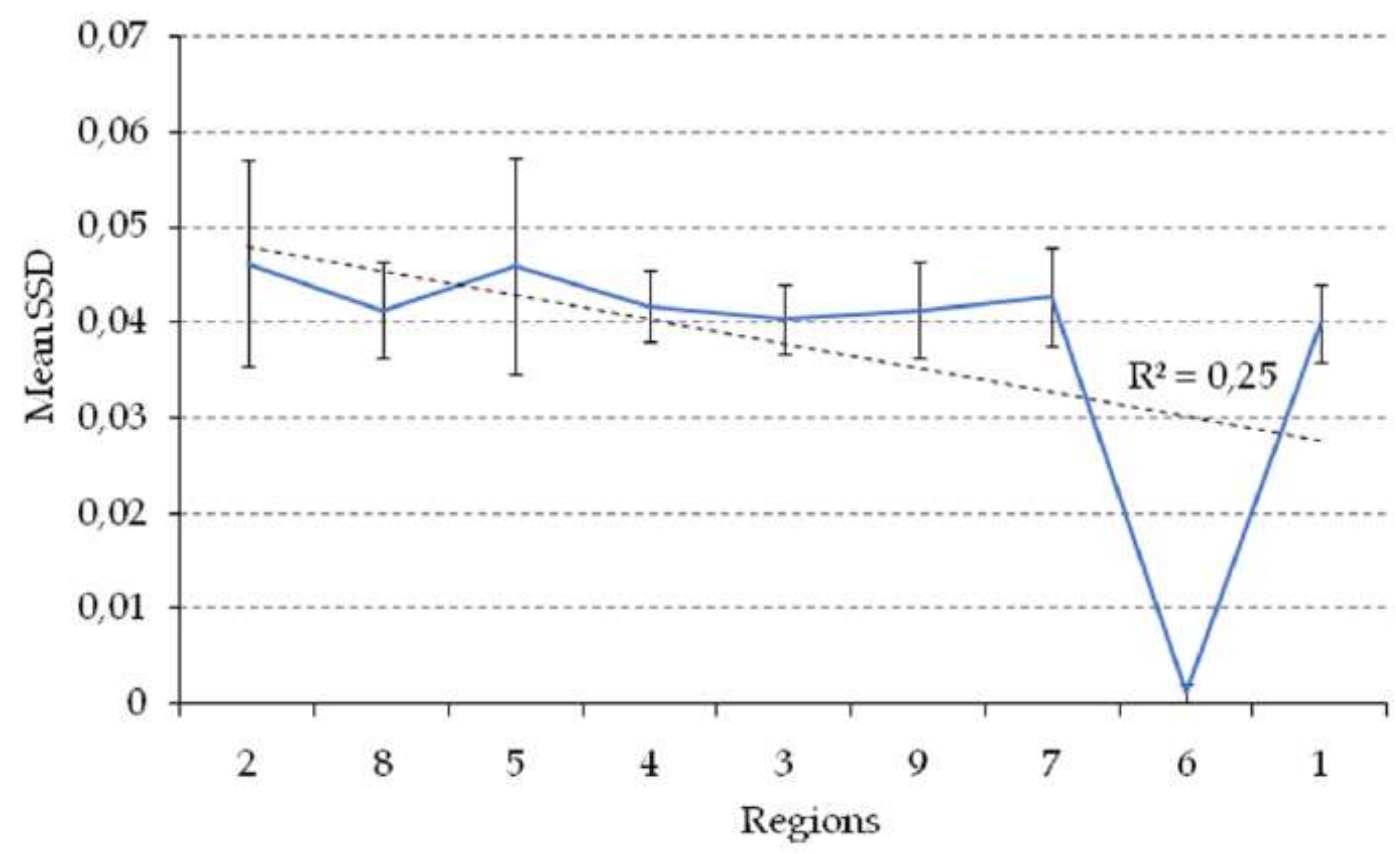

Figure 4. Mean SSD variation. The regions were arranged eastwards. 


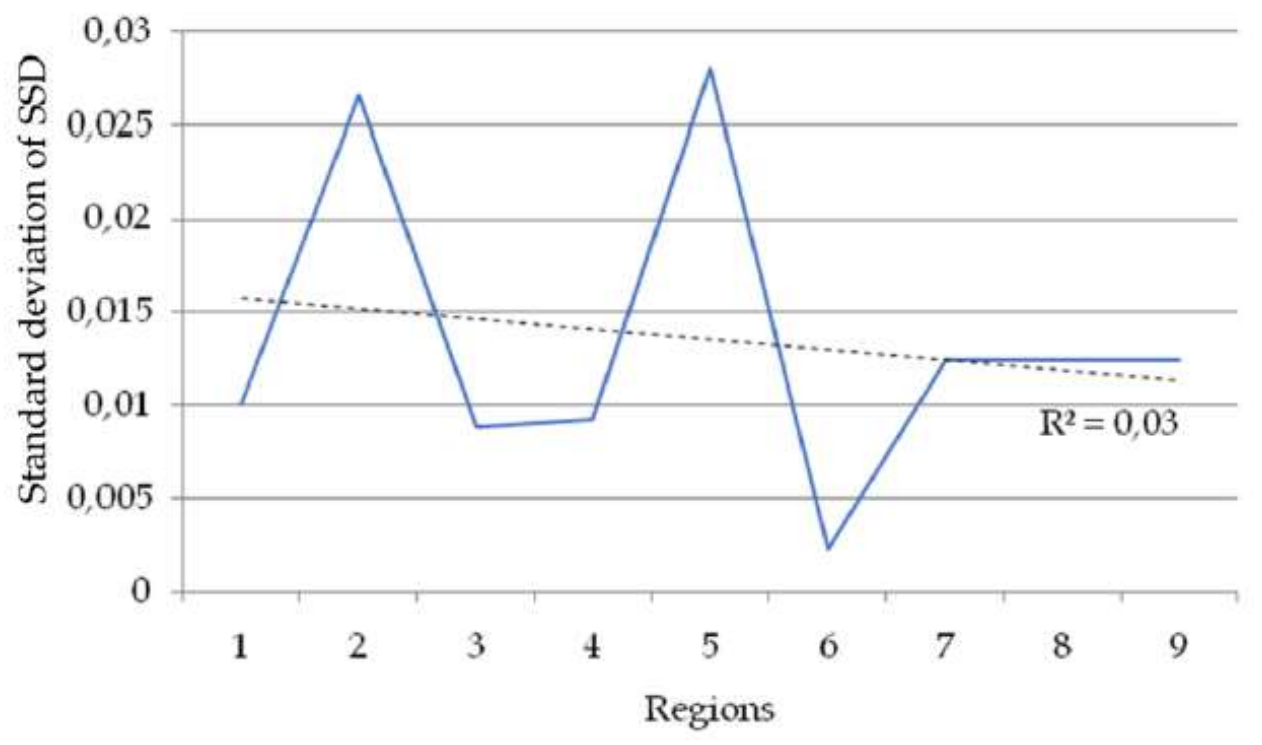

Figure 5. Latitude gradient in standard deviation of SSD in P. oblongopunctatus

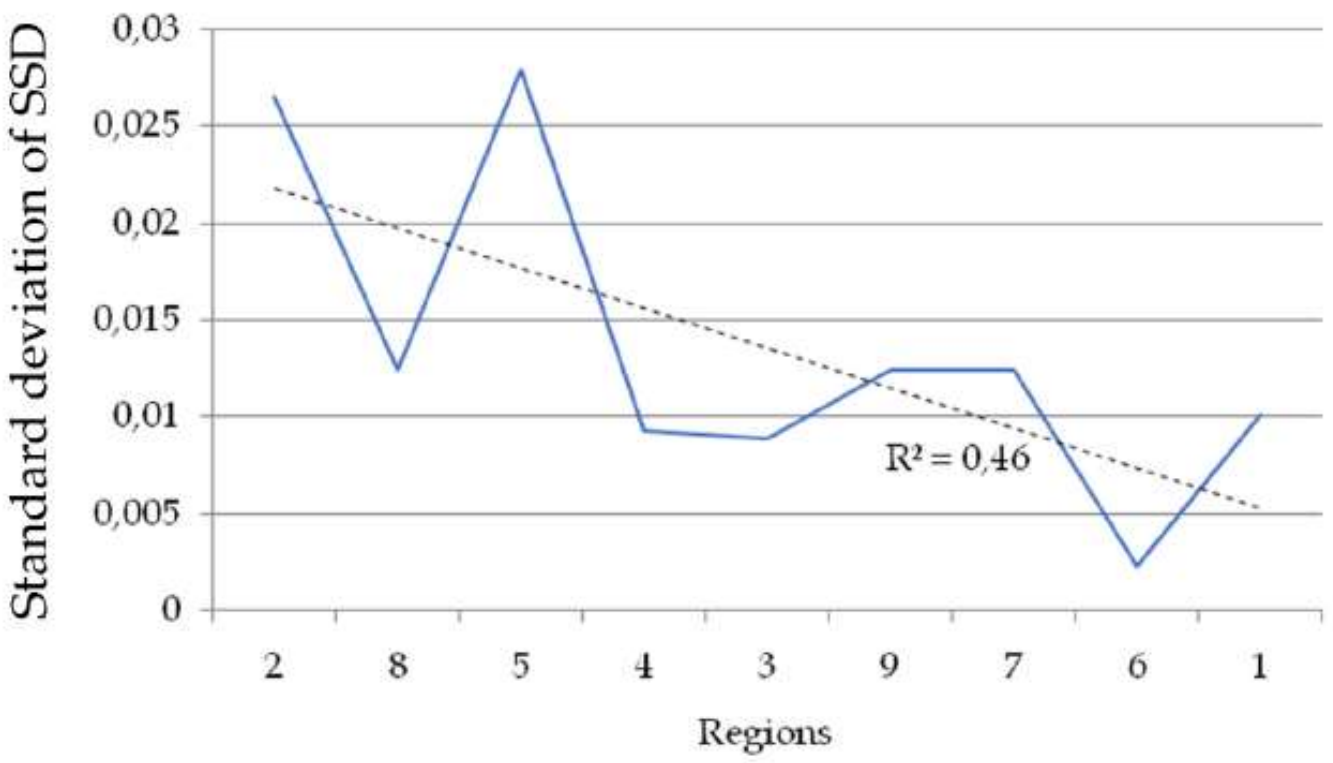

Figure 6. Longitude gradient in standard deviation of SSD in P. oblongopunctatus

We did not take into account the environmental factors in each locality. Anthropogenic press, landscape features, habitat vegetation could impact beetles body size, as it had been published earlier [17-18]. Such variation in size might influence SSD, if the sensitivity to environmental factors differed in both sexes. Alternatively SSD variation in geographical gradients can e genus-specific: in Carabus genus species SSD decreased in latitude gradient but in Pterostichus genus remained unchanged [19].

\section{Conclusion}

SSD in P. oblongopunctatus was female-biased females being larger than males by all traits. Values in SSD did not vary in neither latitude nor longitude gradients, but its standard deviation tended to decrease northwards and eastwards. Such a phenomenon could be associated with the homogenization of habitat conditions at the margins of area or it was genus-specific. Additional researches need in females/males sensitivity to environmental factors to clarify the process. 
Supplementary Materials: There is no supplementary material

Author Contributions: For research articles with several authors, a short paragraph specifying their individual contributions must be provided. The following statements should be used "Conceptualization, R.S. and A.S.; methodology, N.E.; software, A.S.; validation, R.S., R.S. and T.G.; formal analysis, T.G.; investigation, A.S.; resources, N.U.; data curation, I.V.; writing-original draft preparation, T.G.; writing - review and editing, R.S.; visualization, A.A.; supervision, R.S.; project administration, L.T.; funding acquisition, R.S. All authors have read and agreed to the published version of the manuscript.

Funding: This research received no external funding.

Institutional Review Board Statement: Not applicable.

Informed Consent Statement: Not applicable.

Data Availability Statement: Please refer to suggested Data Availability Statements in section "MDPI Research Data Policies" at https://www.mdpi.com/ethics.

Acknowledgments: We thank all staff of corresponding Laboratories, who sampled beetles in different provinces of Russia and Belarus. We thank Elena Belskaya (Institute of Plant and Animal Ecology, Ural Branch, Russian Academy of Sciences) for presenting beetles from Revda region.

Conflicts of Interest: The authors declare no conflict of interest.

\section{References}

1. Chase, J.M.; Leibold, M.A. Ecological niches: Linking classical and contemporary approaches. University of Chicago Press, Chicago, 2003; $221 \mathrm{p}$.

2. Gonza'lez-Salazar, C.; Stephens, C.R.; Marquet, P.A. Comparing the relative contributions of biotic and abiotic factors as mediators of species' distributions. Ecological Modelling 2013, Volume 248; 57-70.

3. Zellweger, F.; Baltensweiler, A.; Ginzler, C.V.; Braunisch, T.R.; Bugmann, H.; Bollmann, K. Environmental predictors of species richness in forest landscapes: abiotic factors versus vegetation structure. Journal of Biogeography 2016, Volume 43, pp.1080-1090.

4. Mirth, C.K.; Shingleton, A.W. Coordinating development: how do animals integrate plastic and robust developmental processes? Frontiers in Cell and Developmental Biology 2019, Volume 7, p. 8.

5. Shingleton, A.W.; Estep, C.M.; Driscoll, M.V.; Dworkin, I. Many ways to be small: Different environmental regulators of size generate distinct scaling relationships in Drosophila melanogaster, Proceedings Biological Sciences, The Royal Society, 2009. Volume 276 (1667), pp. 2625-2633.

6. Blanckenhorn, W.U.; Bauerfeind, S.S.; Berger, D.; Davidowitz, G.; Fox, C.W.; Guillaume, F.; Nakamura, S.; Nishimura, K.; Sasaki, H.; Stillwell, R.C.; Tachi, T.; Schäfer, M.A. Life history traits, but not body size, vary systematically along latitudinal gradients on three continents in the widespread yellow dung fly. Ecography 2018, Volume 41(12), pp. 2080-2091.

7. Clemson, A.S.; Sgrò, C.M.; Telonis-Scott, M. Thermal plasticity in drosophila melanogaster populations from eastern Australia: Quantitative traits to transcripts. Journal of Evolutionary Biology, 2016. Volume 29(12), pp. 2447-2463.

8. Trotta, V.; Calboli, F.C.F.; Ziosi, M.; Guerra, D.; Pezzoli, M.C.; David, J.R.; Cavicchi, S. Thermal plasticity in Drosophila melanogaster: A comparison of geographic populations. BMC Evolutionary Biology 2006, Volume 6, p. 67.

9. Kryzhanovsky, O. Fam. Carabidae - ground beetles. Key to Insects of the European USSR 1965, Volume 2, pp. $29-77$.

10. Sukhodolskaya, R.A.; Saveliev, A.A.; Ukhova, N.L.; Vorobyova, I.G.; Solodovnikov, I.A.; Anciferov, A.L.; Gordienko, T.A.; Shagidullin, R.R.; Vavilov, D.N. Modeling sexual differences of body size variation in ground beetles in geographical gradient (The case study in Pterostichus oblongpunctatus Fabricius, 1787). GSC Biological and Pharmaceutical Sciences 2020, Volume 13(03), pp. 149-161.

11. Brygadyrenko, V.V. Evaluation of ecological niches of abundant species of Poecilus and Pterostichus (Coleoptera: Carabidae) in forests of steppe zone of Ukraine. Entomologica Fennica 2016, Volume 27, pp. 81-100.

12. Avtaeva, T.A.; Sukhodolskaya, R.A.; Skripchinsky, A.V.; Brygadyrenko, V.V. Range of Pterostichus oblongopunctatus (Coleoptera, Carabidae) in conditions of global climate change. Biosystems Diversity 2019, Volume 27.

13. Belskaya, E.A.; Zolotarev, M.P.; Zinovyev, E.V. Carabidae assemblages in pine forests with different recreation regimes within and outside a megalopolis. Urban Ecosystems 2020, Volume 23, pp. 27-38. 
14. Mukhametnabiev, T.R.; Sukhodolskaya, R.A.; Vorobyova, I.G.; Antsiferov, A.L.; Ukhova, N.L. Influence of geographic location in area and dominant forest forming species on body shape of ground beetle Pterostichus oblongopunctatus Fabricius, 1787 (Coleoptera: Carabidae) in taiga-broadleaf gradient in Russia. Российский журнал прикладной экологии 2020, N 1, C. 3-12.

15. Lovich, J.E.; Gibbons, J.W. A review of techniques for quantifying sexual size dimorphism. Growth development and Aging. 1992, Volume 56, pp. 269-281.

16. Sukhodolskaya, R.A.; Saveliev, A.A.; Muhammetnabiev, T.R. Sexual Dimorphism of Insects and Conditions of Its Manifestation. Research Journal of Pharmaceutical, Biological and Chemical Sciences, 2016. Volume 7(2). pp. 1992-2001.

17. Sukhodolskaya R. Variation in Body Size and Body Shape in Ground Beetle Pterostichus melanarius Ill. (Coleoptera, Carabidae). Journal of Agri-Food and Applied Sciences 2014, Volume 2(7), pp. 196-205.

18. Sukhodolskaya R.A.; Eremeeva N.I. Body size and shape variation in Ground Beetle Carabus aeruginosus F.-W., 1822 (Coleoptera, Carabidae). Contemporary Problems of Ecology, 2013, Volume 6, Issue 6, pp. 609-615.

19. Sukhodolskaya, R.A.; Saveliev, A.A.; Gordienko, T.A.; Vavilov, D.N. Sexual size dimorphism in Ground Beetles and its modeling in latitude gradient. GSC Biological and Pharmaceutical Sciences 2018, Volume 3 (1), pp. 11-18. 